\title{
Successful surgical management of ventricular fibromas in children
}

\author{
Meena Nathan, MD, ${ }^{\mathrm{a}}$ Assunta Fabozzo, MD, ${ }^{\mathrm{a}}$ Tal Geva, MD, ${ }^{\mathrm{b}}$ Edward Walsh, MD, ${ }^{\mathrm{b}}$ and \\ Pedro J. del Nido, MD
}

\begin{abstract}
Objectives: A uniform management strategy has not been established for the treatment of large ventricular fibromas identified in children. The goal of the present study was to review our experience with surgical resection of this uncommon tumor.
\end{abstract}

\begin{abstract}
Methods: We performed a retrospective review of all patients with a diagnosis of ventricular fibromas who had undergone surgical intervention at our institution from July 1990 to June 2013. The clinical records and pathology reports were reviewed and available follow-up data obtained.
\end{abstract}

Results: A total of 20 patients had a ventricular fibroma. The median age at presentation was 4 years (range, 5 months to 12 years). Of these, $18(89 \%)$ presented with ventricular tachycardia $(\mathrm{n}=15)$ or frequent ectopy $(\mathrm{n}=3)$, and $1(6 \%)$ with outflow tract obstruction; $1(6 \%)$ was asymptomatic and diagnosed during routine evaluation for a murmur. One patient had undergone previous ablation, and one had had an automated internal cardiac defibrillator implanted for ventricular tachycardia control. Before tumor resection at our institution, 1 patient had been listed for transplantation at an outside institution and 1 had undergone previous extracardiac Fontan without tumor resection. All patients underwent successful tumor excision with no recurrence of ventricular arrhythmia during a median follow-up period of 3.3 years (range, 1 month to 14.7 years). One patient underwent planned staged tumor resection. No patient died.

Conclusions: Primary ventricular fibromas, even when very large, can be managed by surgical resection, with excellent short- and intermediate-term ventricular function and relief of arrhythmic events. (J Thorac Cardiovasc Surg 2014;148:2602-8)

Benign cardiac tumors represent $75 \%$ of all cardiac tumors, which have an incidence of $0.001 \%$ to $0.3 \%$ in autopsy series. Cardiac fibromas represent the second most common benign pediatric tumor. ${ }^{1-3}$ Autopsy studies of fibroma were reported as early as 1855 , and the first case reports were published in $1949 .{ }^{4}$ Since then, these tumors have been described in numerous case reports. ${ }^{5,6}$ Although major strides have been made in establishing the diagnosis, especially with noninvasive imaging, ${ }^{7}$ management strategies, in particular, surgical strategies, have not been well-defined. ${ }^{8-23}$

The goal of the present study was to review our institutional experience with surgical management of ventricular fibromas, with special attention to the surgical techniques used for successful resection and amelioration of the potentially life-threatening arrhythmias. We chose to focus on the outcomes of patients who had undergone surgical management of symptomatic ventricular fibroma,

From the Departments of Cardiac Surgery ${ }^{\mathrm{a}}$ and Cardiology, ${ }^{\mathrm{b}}$ Boston Children's Hospital and Harvard Medical School, Boston, Mass.

Disclosures: Tal Geva reports consulting fees from Medtronic. All other authors have nothing to disclose with regard to commercial support.

Received for publication Sept 11, 2013; revisions received Nov 4, 2013; accepted for publication Nov 15, 2013; available ahead of print Feb 5, 2014.

Address for reprints: Meena Nathan, MD, Department of Cardiac Surgery, Boston Children's Hospital and Harvard Medical School, 300 Longwood Ave, Bader 273, Boston, MA 02215 (E-mail: meena.nathan@cardio.chboston.org).

$0022-5223 / \$ 36.00$

Copyright (c) 2014 by The American Association for Thoracic Surgery

http://dx.doi.org/10.1016/j.jtcvs.2013.11.052 because reports have varied on the ideal management of these tumors and have included resection, transplantation, and single ventricle palliation.

\section{METHODS}

A retrospective review of all patients with a tissue diagnosis of ventricular fibroma who had undergone tumor resection at our institution from July 1990 to June 2013 was performed. The institutional review board approved the conduct of our review. We queried our cardiac surgical, cardiology, echocardiography, and pathology databases during the study period for all patients who presented to our institution with a diagnosis of fibroma. The clinical records were reviewed for clinical history and operative data. The reports of all pre- and postoperative imaging studies, including echocardiograms; magnetic resonance imaging, cardiac catheterization, and electrophysiologic studies; electrocardiograms; and Holter monitor studies were reviewed. The pathology reports were examined for confirmation of the diagnosis. All operative reports were reviewed to document the surgical technique at resection. Special attention was given to the tumor location and completeness of resection.

\section{RESULTS}

From 1990 to 2013, 153 patients were identified with cardiac tumors: 92 rhabdomyoma, 26 fibroma, 10 myxoma, 5 vascular, 3 teratoma, 3 lipoma, and 14 other tumors. In this group of 153 patients, 53 underwent cardiac tumor resection, with resection of ventricular fibromas in 20 patients. All patients who were referred to our center for symptoms underwent resection; none were deemed inoperable or considered for palliative procedures, such as single ventricle palliation, and none were evaluated for 


\section{Abbreviation and Acronym}

$\mathrm{ECMO}=$ extracorporeal membrane oxygen

transplantation. Of these 20 tumors, 18 were located in the left ventricle and 2 in the right. The distribution between males and females was equal (10 each). The median age at resection was 4.2 years (range, 5 months to 12 years). The median follow-up duration was 3.3 years (range, 0.1-14.7 years). No patient died. One patient who had had 2 separate large tumors required staged resection, with removal of the anteroseptal tumor first, followed by removal of the second tumor arising in close proximity to the atrioventricular groove, in a subsequent procedure. Seven patients required additional intracardiac work (atrioventricular valve repair in 5, patent foramen ovale closure in 1 , and Fontan conversion in 1). Of the 20 patients, 18 (90\%) presented with some form of ventricular arrhythmia, ranging from frequent premature ventricular beats to sustained or nonsustained ventricular tachycardia; with 1 patient experiencing a ventricular fibrillatory arrest. One patient was referred after undergoing staged single ventricle management, including Stansel connection at birth and, later, an extracardiac Fontan. One patient had been deemed inoperable and listed for transplantation at an outside

TABLE 1. Summary of patient and procedure characteristics $(n=20)$

\begin{tabular}{l}
\multicolumn{1}{c}{ Characteristic } \\
\hline Preoperative \\
Male gender \\
Median age $(\mathrm{y})$ \\
Weight $(\mathrm{kg})$ \\
Preoperative findings \\
Asymptomatic \\
Ventricular arrhythmias \\
RVOTO \\
Intraoperative \\
Median on-pump time $(\mathrm{min}, \mathrm{n}=20)$ \\
Median fibrillatory time $(\mathrm{n}=8)$ \\
Median crossclamp time $(\mathrm{n}=10)$ \\
Associated procedure $(6 / 20$ patients $[30 \%])$ \\
Biventricular conversion from Fontan \\
Mitral valve repair \\
Tricuspid valve repair \\
PFO closure \\
Postoperative \\
ECMO \\
Median length of stay $(\mathrm{d})$ \\
Median follow-up $(\mathrm{y})(\mathrm{n}=17 / 20 *)$ \\
Death \\
Reoperation \\
Ventricular arrhythmia \\
\hline
\end{tabular}

Value

$10(50 \%)$
$4.21(0.44-12.45)$
$16.9(6.9-55.9)$
1
18
1

$112(62-363)$

$52(5-233)$

$70(8-98)$

Data presented as median (range) or $\mathrm{n}(\%)$. RVOTO, Right ventricular outflow tract obstruction; $P F O$, patent foramen ovale; $E C M O$, extracorporeal membrane oxygen. *The 3 patients lost to follow-up were all from outside the United States. institution, before successful tumor resection at our institution. There was no recurrence of arrhythmia postoperatively in any of the 20 patients during early and late follow-up. The patient and tumor characteristics are listed in Table 1, the imaging characteristics in Table 2, and the individual patient data in Table 3. A graphic representation of the tumor location is presented in Figure 1. Figure 2 shows the magnetic resonance imaging, intraoperative, and histologic findings from a representative case.

\section{Surgical Technique}

All procedures were performed with cardiopulmonary bypass and moderate hypothermia $\left(28^{\circ} \mathrm{C}\right.$ in $11,25^{\circ} \mathrm{C}$ in 5). More recently, 7 patients underwent this procedure using a lower hemisternotomy with excellent tumor visualization. All but 2 patients had undergone bicaval cannulation. Early in our experience, cardioplegic arrest was used in 3 patients. In the more recent era (since 2004), resection has been performed with a beating heart in 5 . In the other 12 patients, tumor resection was performed with the patient under fibrillatory arrest (induced in 6 and spontaneous in 6), because this was believed to allow better delineation of the epicardial coronary arteries that needed to be preserved. Six patients had undergone tumor resection with a beating or fibrillating heart and then underwent cardioplegic arrest

TABLE 2. Preoperative and postoperative findings

\begin{tabular}{|c|c|c|}
\hline Variable & $\begin{array}{c}\text { Preoperative } \\
\text { findings }(n=20)\end{array}$ & $\begin{array}{c}\text { Postoperative } \\
\text { findings }(n=14)\end{array}$ \\
\hline \multicolumn{3}{|c|}{ LVEF echocardiogram (n) } \\
\hline$>55 \%$ & 19 & 11 \\
\hline $40 \%-55 \%$ & 1 & 3 \\
\hline$<40 \%$ & 0 & 0 \\
\hline \multicolumn{3}{|l|}{ LVEF MRI } \\
\hline Mean \pm SD & $61 \pm 10$ & NA \\
\hline Median & 64 & \\
\hline Range & $35-72$ & \\
\hline \multicolumn{3}{|l|}{ LVEDVi MRI } \\
\hline Mean \pm SD & $78 \pm 18$ & NA \\
\hline Median & 81 & \\
\hline Range & $38-115$ & \\
\hline \multicolumn{3}{|l|}{ Tumor length $(\mathrm{cm})$} \\
\hline Mean \pm SD & $5.4 \pm 1.3$ & NA \\
\hline Median & 5 & \\
\hline Range & 3-8.6 & \\
\hline \multicolumn{3}{|c|}{ Associated findings (n) } \\
\hline Residual AVVR* & NA & 4 \\
\hline Residual tumor $\dagger$ & & 8 \\
\hline RVOT aneurysm & & 1 \\
\hline Arrhythmia & 18 & 0 \\
\hline
\end{tabular}


TABLE 3. Detailed patient characteristics of ventricular fibromas (presenting symptoms, tumor location, follow-up data)

\begin{tabular}{|c|c|c|c|c|c|}
\hline Pt. no. & Age & Presentation & Preoperative workup & Tumor location & Preoperative arrhythmia \\
\hline 1 & $7.5 \mathrm{mo}$ & $\begin{array}{l}\text { Murmur } \\
\text { RVOTO }\end{array}$ & $\begin{array}{l}\text { Echo } \\
\text { MRI }\end{array}$ & $\begin{array}{l}\text { RV free wall to left of RVOT, with } \\
\text { RVOTO }\end{array}$ & None \\
\hline 2 & $7 \mathrm{mo}$ & URI symptoms, FTT & Echo, MRI & $\begin{array}{l}\text { Anterolateral LV free wall from base } \\
\text { to ALPM and extending } \\
\text { over proximal LCA }\end{array}$ & Holter 132 VPB \\
\hline 3 & $6 y$ & Palpitation & Echo, MRI & PL LV free wall from base to apex & Holter 438 PVCs, 74 runs of VT \\
\hline 4 & $6 \mathrm{y}$ & Ectopy during T\&A & Echo, MRI & Inferoseptal and apical wall of LV & Vent ectopy \\
\hline 5 & $3 \mathrm{y}$ & Murmur & Echo, EPS, Cath, MRI & $\begin{array}{l}\text { Intramyocardial LV mass involving } \\
\text { high septum and anterolateral wall }\end{array}$ & $\begin{array}{l}\text { Holter-nonsustained VT, PVCs, } \\
\text { couplets, bigeminy }\end{array}$ \\
\hline 6 & $10.5 \mathrm{y}$ & CXR for URI symptoms & Echo, Cath & $\begin{array}{l}\text { LV apical anterolateral free wall and } \\
\text { anterior septum }\end{array}$ & $\begin{array}{l}\text { ETT isolated, multifocal and slow } \\
\text { ventricular couplets, ventricular } \\
\text { triplets, and one 4-beat run of } \\
\text { slow VT }\end{array}$ \\
\hline 7 & $12.5 \mathrm{y}$ & Tachycardia during a febrile illness & $\begin{array}{l}\text { Echo, MRI } \\
\text { EPS, Cath }\end{array}$ & Anterolateral free wall & Sustained monomorphic VT \\
\hline 8 & $4.5 \mathrm{y}$ & CXR for URI & Echo, Cath & $\begin{array}{l}\text { LV free wall from level of ALPM to } \\
\text { just above LV apex }\end{array}$ & $\begin{array}{l}\text { Holter- occasional PVC, } 2 \text { couplets, } \\
1 \text { triplet, one } 6 \text { beat run of } \\
\text { accelerated idioventricular rhythm }\end{array}$ \\
\hline 9 & $11 \mathrm{y}$ & ER admission with SOB & Echo & Apical LV mass, extension into ALPM & Recurrent VT \\
\hline 10 & $6 \mathrm{y}$ & $\begin{array}{l}\text { Wide complex tachycardia } \\
\text { hemiparesis, factor V Leiden } \\
\text { mutation }\end{array}$ & Echo, MRI & $\begin{array}{l}\text { Lateral aspect of LV free wall, possible } \\
\text { involvement of ALPM }\end{array}$ & Sustained VT \\
\hline 11 & $4 \mathrm{y}$ & Vfib arrest at 2 mo & Echo, MRI & $\begin{array}{l}\text { Tumor involving inferior and } \\
\text { inferolateral wall of LV, closely } \\
\text { associated with PMPM }\end{array}$ & $\begin{array}{l}\text { Vfib arrest at } 2 \text { mo, subsequent runs of } \\
\text { monomorphic VT on Holter despite } \\
\text { antiarrhythmic agents }\end{array}$ \\
\hline 12 & $4 \mathrm{y}$ & Wide complex tachycardia & Echo, EPS, Cath & Tumor along inferolateral wall of LV & $\begin{array}{l}\text { Wide complex tachycardia, EPS } 1 \text {, } \\
\text { spontaneous self-resolving VT, } \\
\text { inducible VT } \times 2 \text { foci requiring } \\
\text { cardioversion }\end{array}$ \\
\hline 13 & $8 \mathrm{mo}$ & Murmur & Echo, Cath, MRI & $\begin{array}{l}\text { IVS from base to apex, abutting } \\
\text { PMPM and commissure }\end{array}$ & $\begin{array}{l}\text { No preoperative arrhythmia, referred } \\
\text { to surgery for increasing tumor size }\end{array}$ \\
\hline 14 & $5 \mathrm{mo}$ & Diagnosis on fetal Echo & $\begin{array}{l}\text { Echo, Cath, } \\
\text { EPS, Cath }\end{array}$ & $\begin{array}{l}\text { Lateral wall of LV extending from base } \\
\text { to apex }\end{array}$ & $\begin{array}{l}\text { Monomorphic VT, inducible VT on } \\
\text { EPS }\end{array}$ \\
\hline 15 & $4.5 \mathrm{y}$ & Presyncope & Echo, MRI & $\begin{array}{l}\text { Anterolateral and lateral wall from } \\
\text { base to midway to apex }\end{array}$ & Presyncope nonsustained VT \\
\hline 16 & $2 \mathrm{y}$ & Murmur & Echo, MRI, Cath & $\begin{array}{l}\text { LV free wall extending from } \\
\text { base to } 2 / 3 \text { of distance to apex, mild sub-AS }\end{array}$ & $\begin{array}{c}\text { Non sustained VT on Holter, inducible } \\
\text { poly- or monomorphic VT on EPS }\end{array}$ \\
\hline 17 & $10 \mathrm{mo}$ & VT & Echo, MRI, CT & $\begin{array}{l}\text { Inferior LV wall extending from base } \\
\text { to apex, no OTO }\end{array}$ & VT \\
\hline 18 & $5.3 \mathrm{y}$ & Ventricular arrhythmias & Echo, MRI & $\begin{array}{l}\text { Anteroseptal wall extending to base } \\
\text { of LV }\end{array}$ & Premature ventricular beats, unifocal \\
\hline 19 & $7.5 \mathrm{mo}$ & VT & Echo, MRI, Cath & $\begin{array}{l}\text { Anteroseptal, anterior and } \\
\text { anterolateral segments, extending } \\
\text { from base to nearly apex }\end{array}$ & VT \\
\hline 20 & $8.5 \mathrm{y}$ & VT & Echo, MRI & Anterior free wall right ventricle & Asymptomatic VT on Holter \\
\hline
\end{tabular}

Pt. no., Patient number; RVOTO, right ventricular outflow tract obstruction; FU, follow-up; Echo, echocardiogram; MRI, magnetic resonance imaging; RV, right ventricular/ ventricle; $R V O T$, RV outflow tract; $U R I$, upper respiratory infection; $F T T$, failure to thrive; $L V$, left ventricular/ventricle; $A L P M$, anterolateral papillary muscle; $L C A$, left coronary artery; $V P B$, ventricular premature beat; $P L$, posterolateral; $P V C s$, premature ventricular contractions; $V T$, ventricular tachycardia; $T \& A$, tonsillectomy and adenoidectomy; $E P S$, electrophysiologic study; Cath, cardiac catheterization; $C X R$, chest radiograph; ETT, exercise test; LAD, left anterior descending (artery); $L C A$, left coronary artery; $E F$, ejection fraction; $E R$, emergency room; $A I C D$, automatic implantable cardioverter defibrillator; $A V$, atrioventricular; $P F O$, patent foramen ovale; $V f i b$, ventricular fibrillation; $I V S$, interventricular septum; PMPM, posteromedial papillary muscle; $M V$, mitral valve; $A S$, aortic stenosis; $M R$, mitral regurgitation; $O T O$, outflow tract obstruction.

for inspection of the atrioventricular valve or subaortic region or for patent foramen ovale closure. The left heart was decompressed by a right superior pulmonary vein vent. Once cardiopulmonary bypass had been initiated, careful examination of the tumor for its proximity to the major coronary arteries and atrioventricular grove was performed, and the ideal incision site for resection was determined. The epicardial incision was made, taking care 
TABLE 3. Continued

\begin{tabular}{|c|c|c|c|}
\hline Surgery & FU duration & $\begin{array}{l}\text { Reintervention } \\
\text { after discharge }\end{array}$ & Current status \\
\hline Complete resection of $\mathrm{RV}$ mass & $14.7 \mathrm{y}$ & None & $2.8 \times 1.5 \mathrm{~cm}$ RVOT aneurysm, no arrhythmia \\
\hline Near complete resection of LV fibroma & $11.5 \mathrm{y}$ & None & Mild global LV systolic dysfunction, no arrhythmias \\
\hline Complete resection of LV tumor & $1 \mathrm{mo}$ & None & Lost to FU \\
\hline Complete resection of LV apical tumor & $1 \mathrm{mo}$ & None & Lost to FU \\
\hline $\begin{array}{l}\text { Subtotal Excision of LV fibroma, (thin rim of tumor to } \\
\text { protect epicardial coronaries and septum) }\end{array}$ & $8.6 \mathrm{y}$ & None & $\begin{array}{l}\text { Normal LV function on echo, residual tumor on MRI in } \\
\text { anterior basal septum, no arrhythmias }\end{array}$ \\
\hline $\begin{array}{l}\text { Resection of LV tumor, a thin rim of residual tissue beneath } \\
\text { LAD, PFO closure }\end{array}$ & $8.4 \mathrm{y}$ & None & $\begin{array}{l}\text { Apex and apical portion of LV thin and slightly echo-bright, } \\
\text { mildly generous aortic annulus, no arrhythmia }\end{array}$ \\
\hline $\begin{array}{l}\text { Excision of LV tumor, with a thin rim of tumor beneath LCA } \\
\text { and ventricular septum }\end{array}$ & $8.9 \mathrm{y}$ & None & $\begin{array}{l}\text { Mildly dilated LV with minimally depressed function EF } \\
49.7 \% \text {, Holter: VPBs with no runs of VT }\end{array}$ \\
\hline Complete excision of LV tumor & $9 \mathrm{y}$ & None & Good LV function, Holter single isolated PVC \\
\hline Complete excision of tumor, and removal of AICD leads & $6.9 \mathrm{y}$ & None & Low normal LV function, EF $42.8 \%$, no arrhythmia \\
\hline $\begin{array}{l}\text { Excision of tumor leaving a thin rim of tumor at } \mathrm{AV} \text { groove } \\
\text { and under diagonal branch, PFO closure }\end{array}$ & $5.5 \mathrm{y}$ & None & $\begin{array}{l}\text { Residual hemiparesis, no significant change in residual } \\
\text { tumor size, no arrhythmia }\end{array}$ \\
\hline Complete tumor resection & $4 \mathrm{y}$ & None & Well, no arrhythmia \\
\hline Total tumor excision & $1 \mathrm{mo}$ & None & Lost to FU \\
\hline $\begin{array}{l}\text { Enucleation of apical tumor, MV plasty, and sub-AS } \\
\text { inspection }\end{array}$ & $3.7 \mathrm{y}$ & $\begin{array}{l}\text { Planned staged resection } \\
\text { LV, septal fibroma mitral } \\
\text { valvuloplasty, sub-AS } \\
\text { resection }\end{array}$ & $\begin{array}{l}\text { Mild LV dysfunction, EF } 42 \% \text {, moderate MR unchanged } \\
\text { from previously, no LVOTO, no residual tumor, no } \\
\text { arrhythmia }\end{array}$ \\
\hline $\begin{array}{l}\text { Resection of tumor, leaving behind a thin rim of tumor at } \mathrm{AV} \text {, } \\
\text { MV plasty }\end{array}$ & $2.5 \mathrm{y}$ & None & $\begin{array}{l}\text { Mild global LV dysfunction, improved from previous, large } \\
\text { cavernous region near LV apex, mild MR, no LVOTO } \\
\text { Holter: } 3 \text { PVC, } 3 \text { PAC }\end{array}$ \\
\hline Complete tumor excision & $3 y$ & None & Well, no arrhythmia, no recurrence \\
\hline $\begin{array}{l}\text { Major tumor debulking, ligation of coronary branch running } \\
\text { into tumor }\end{array}$ & $1.5 \mathrm{y}$ & None & Well, no arrhythmia \\
\hline Total excision of LV fibroma, MV repair & $6 \mathrm{mo}$ & None & Well, no arrhythmia \\
\hline $\begin{array}{l}\text { Excision of LV fibroma biventricular conversion from } \\
\text { Fontan, ECMO }\end{array}$ & $5 \mathrm{mo}$ & None & Well, no arrhythmia \\
\hline Excision of LV fibroma, mitral valvuloplasty, ECMO & 4 mo & None & Well, no arrhythmia \\
\hline $\begin{array}{l}\text { Excision of RV fibroma, tricuspid valvuloplasty, PFO } \\
\text { closure }\end{array}$ & $2 \mathrm{mo}$ & None & Well, no arrhythmia \\
\hline
\end{tabular}

to avoid the coronary arteries, at the point of maximal prominence of the tumor, and the incision was continued parallel to the major coronary arteries. The plane between the epicardium and tumor was developed and was often well-delineated, because the tumor had a typical whitish fibrous texture. Every attempt was made to enucleate the entire tumor. Occasionally, transmural resection with entry into either ventricular cavity was required. A thin layer of 


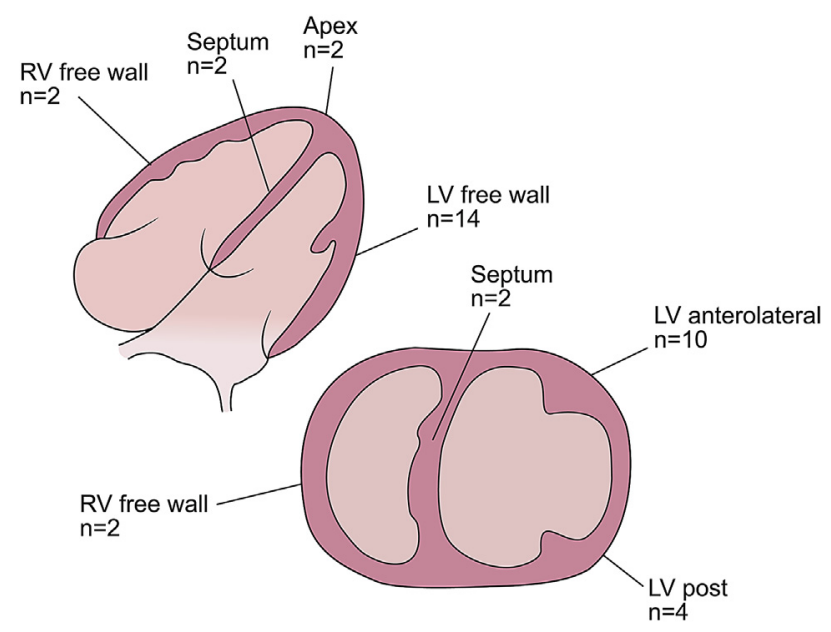

FIGURE 1. Location of fibromas. Most were in the left ventricular $(L V)$ free wall. $R V$, Right ventricular.

residual tumor was left behind if it had extended close to the atrioventricular groove or close to a major epicardial coronary artery. Once complete or near complete tumor resection had been confirmed by the presence of viable myocardial tissue in the tumor bed, the tumor bed was obliterated with interrupted pledgetted Prolene sutures in layers, taking care to avoid any kinking of the epicardial coronary arteries. In most cases, the epicardium was reapproximated over the obliterated tumor bed with fine Prolene sutures. If any concern for coronary compromise was present, the tumor bed was left partially open. Any intracardiac work that was required (eg, inspection and/or repair of the atrioventricular valve, inspection of the left ventricular outflow tract, closure of a patent foramen ovale) was then performed with the patient under cardioplegic or fibrillatory arrest. The left heart was de-aired, and the patients were weaned off cardiopulmonary bypass once they had been rewarmed. Atrial and ventricular wires were routinely placed, and all but 4 patients underwent primary chest closure.

Concomitant atrioventricular valve repair was performed in 5 patients ( 4 mitral valve and 1 tricuspid valve). This

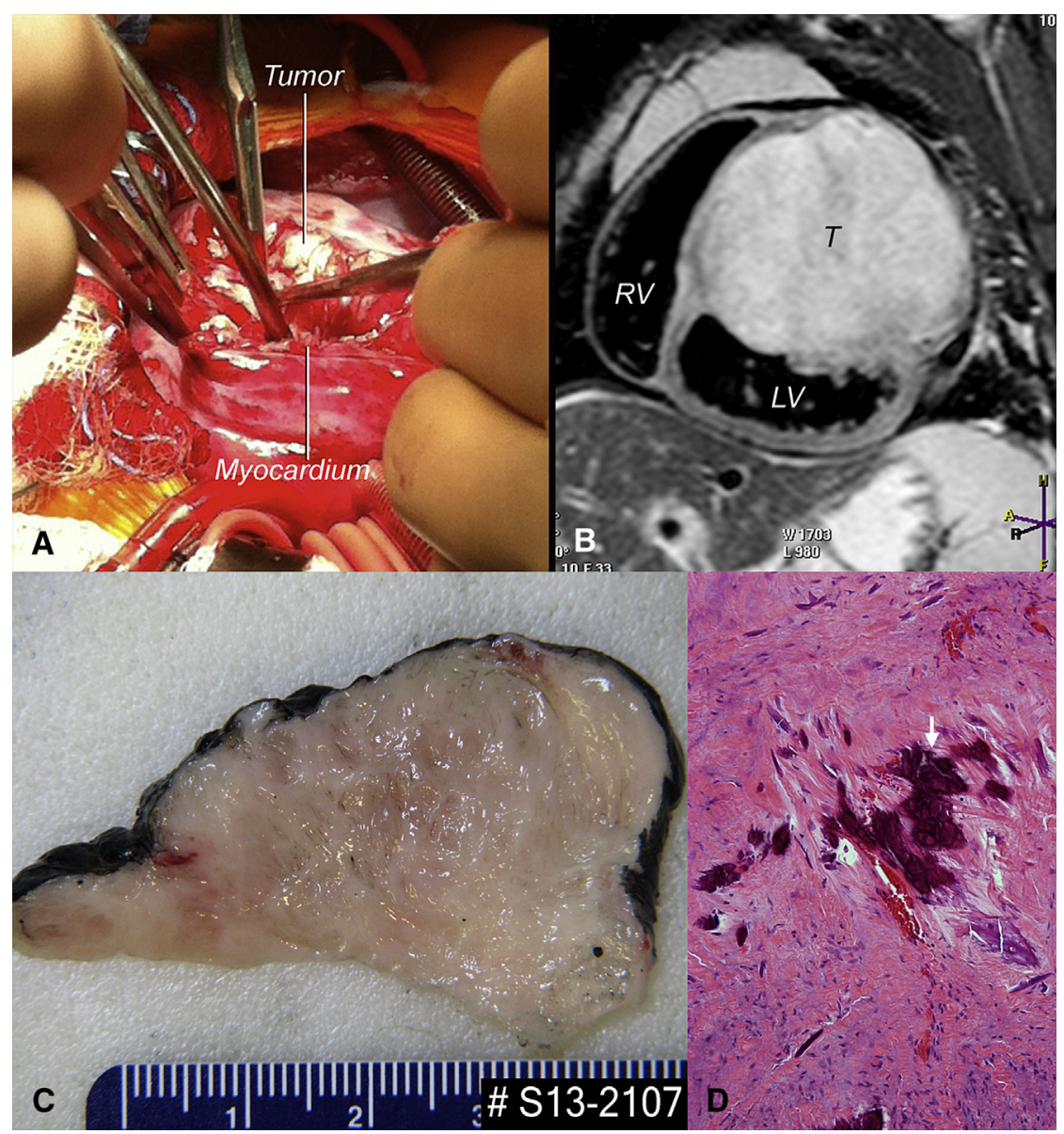

FIGURE 2. Resection of a large left ventricular fibroma in a 7-month-old girl with ventricular tachycardia. A, Intraoperative photograph showing resection of the tumor along the plane of the normal myocardium. $\mathrm{B}, \mathrm{T}_{1}$-weighted magnetic resonance image of the tumor in the ventricular short-axis showing the anatomic features of the mass. C, Gross pathologic specimen showing a somewhat inhomogeneous white-gray solid tumor mass. D, Photomicrograph showing dense collagen, focal necrosis, and calcifications (arrow). $L V$, Left ventricle; $R V$, right ventricle; $T$, tumor. 
included release of tethering cords of the anterior mitral leaflet at the posteromedial commissure, reapproximation of the anterior mitral leaflet, and annuloplasty; partial closure of the anterolateral commissure, which was splayed open; anterolateral and posteromedial commissuroplasty for prolapse of the posterior mitral leaflet; release of the abnormal attachments at anterolateral commissure with partial closure of the commissure; and anteroseptal commissure closure and commissuroplasty to reduce tricuspid valve annulus. During follow-up, all patients had stable or an improved grade of atrioventricular valve regurgitation.

Only 3 patients experienced ventricular tachycardia with weaning off of cardiopulmonary bypass. One responded to intravenous lidocaine and a lidocaine infusion was continued for 72 hours postoperatively. The second required reinstitution of cardiopulmonary bypass and take down of the left internal mammary artery in preparation for coronary artery bypass grafting owing to concerns of ischemia in the circumflex coronary territory. However, this patient subsequently recovered normal function and was free of ectopy after a period of support with cardiopulmonary bypass and did not under go coronary artery bypass graft. In both these patients, the chest was left open, with tourniquets in place; however, they did not require any additional intervention, and the chest was closed within the next 24 hours in the first patient and 72 hours in the second patient. The third patient was weaned off bypass onto extracorporeal membrane oxygen (ECMO) support for ventricular arrhythmias that had responded to lidocaine. This patient required ECMO for 3 days and was successfully decannulated.

In addition, the patient who had undergone tumor resection followed by biventricular conversion from Fontan circulation was electively supported with ECMO for left atrial hypertension, with a plan for continued postoperative mechanical support to allow for left ventricular remodeling. This patient continued with ECMO support for 5 days and required peritoneal dialysis for acute renal failure. The patient was successfully decannulated on postoperative day 5 , with subsequent resolution of the renal dysfunction.

Most patients were extubated within 24 to 72 hours of surgery (except for the 2 patients requiring mechanical support; 1 remained ventilated for 14 days and 1 for 8 days). Only 1 patient had a period of junctional rhythm postoperatively; however, no ventricular arrhythmia was documented in the postoperative period in any patient. The findings of a postoperative ventricular stimulation study in 7 patients using their epicardial wires were all negative. Of the 20 patients, $14(70 \%)$ had been placed on antiarrhythmic agents preoperatively and $11(55 \%)$ were discharged with antiarrhythmic medication. During the follow-up period, $4(24 \%)$ of the 17 patients with long-term follow-up data available continued with antiarrhythmic medication as prophylactic therapy. None of the 17 patients had evidence of ventricular tachycardia or fibrillation on Holter monitoring during the follow-up period.

\section{DISCUSSION}

Ventricular fibromas are rare primary cardiac tumors. In our series, we treated 20 patients from 1990 to 2013, with 19 of the 20 treated after 2001 . The management strategy, in particular, the surgical approach has not been well established. The large tumor size in relationship to the ventricular chamber has often been considered a limiting factor for complete excision. In our experience, all but 1 of the tumors could be resected in their entirety, independent of the tumor size, tumor location, or patient age.

Several isolated case reports and small case series of complete or partial excision ${ }^{8-15}$ have been published, and these have included techniques such as the Batista ventriculoplasty and Dacron patch sandwich for closure of the tumor bed after resection. The alternative management approaches to cardiac fibroma reported by others included functional single ventricle palliation, ${ }^{16}$ single ventricle palliation as a bridge to transplantation, ${ }^{17}$ partial excision with single ventricle palliation, ${ }^{18}$ initial single ventricular palliation followed by resection, ${ }^{19}$ staged resection, ${ }^{20}$ and orthotopic heart transplantation as a primary surgical option for large fibromas, in particular, those involving the interventricular septum..$^{21,22}$

The largest series to date on the management of cardiac fibroma was reported by Burke and colleagues, ${ }^{23}$ who reported on 23 patients, including adults and children. Of these, 21 had ventricular fibromas; 13 (8 children and 5 adults) underwent resection (8 simple excisions, 4 incomplete excisions, and 5 complex resections, including patching of myocardial defects, valve replacement, or coronary artery bypass grafting). They reported 2 deaths in this group of 13. The group from the Mayo Clinic ${ }^{24}$ reported their experience with surgical resection of ventricular fibromas from 1964 to 2002. That cohort included 12 children (median age, 3 years; range, $0.2-12.4$ ) and 6 adults. Three patients had been referred to their center for cardiac transplantation. They had 1 intraoperative death. Similar to our experience, they reported no recurrent arrhythmias or tumor recurrence in the patients who survived surgery (median follow-up, 8.6 years; range, 0.4-33.4), but 2 did require subsequent mitral valve replacement.

Recent review at our institution ${ }^{25}$ of a retrospective series of cardiac tumors and associated arrhythmias during a 42-year period, found that surgical excision was effective in the management of arrhythmias. This study included 13 of the patients in the current report.

The present series of 20 patients with cardiac fibromas in multiple locations has demonstrated that surgical excision 
and, in most cases, complete enucleation, can be safely performed, with acceptable postoperative ventricular function and relief from potentially life threatening arrhythmia. The mid-term follow-up data have shown no recurrence of major arrhythmia or tumor. Late follow-up data from this group are necessary to determine the longterm efficacy of this approach, although the present length of follow-up would indicate that ventricular dysfunction would not appear to be a problem, despite the magnitude of the tumor at excision. Although single ventricle palliation or orthotopic transplantation could be considered as an alternative, all our patients were successfully treated with, predominantly, complete excision. In the 8 patients who underwent near total excision with a small rim of residual tumor, none have required reoperation to date, and none have developed recurrent ventricular arrhythmia.

\section{Study Limitations}

The present study was a retrospective review; therefore, the follow-up data were not complete for all patients, with a median follow-up period of only 3.4 years. Three patients were lost to follow-up, because they had been referred to us from outside the United States. Despite extensive effort, we were unable to obtain any follow-up information. In addition, 4 patients from our cohort of 20 had undergone surgery within the previous 12 months ( 3 in the previous 6 months). If we excluded those lost to follow-up and those treated within the past 1 year, the median follow-up period would be 6.9 years (range, 2.5-11.5) for those treated since 2001.

Our review only included patients who had undergone surgical resection for symptomatic ventricular fibroma at our institution. Our study was not a comprehensive review of all ventricular tumors. In the same period, 6 additional patients had a diagnosis of fibroma determined by the magnetic resonance imaging characteristics. All these patients were asymptomatic, with no history of arrhythmia, and are followed conservatively.

\section{CONCLUSIONS}

Large ventricular fibromas can be safely managed with primary total or near total excision, with relief of life-threatening arrhythmias and excellent clinical results.

\section{References}

1. Jain D, Maleszewski JJ, Halushka MK. Benign cardiac tumors and tumorlike conditions. Ann Diagn Pathol. 2010;14:215-30.
2. Uzun O, Wilson DG, Vujanic GM, Parsons JM, De Giovanni JV. Cardiac tumours in children. Orphanet J Rare Dis. 2007;2:11.

3. Paramés F, Freitas I, Martins JD, Trigo C, Pinto MF. Cardiac tumors: the 17-year experience of pediatric cardiology department. Rev Port Cardiol. 2009;28: 929-40.

4. Kulka W. Intramural fibroma of the heart. Am J Pathol. 1949;25:549-57.

5. James U, Stanfield MH. A case of fibroma of the left ventricle in a child of 4 years. Arch Dis Child. 1955;30:187-92.

6. Heath D. Cardiac fibroma. Br Heart J. 1969;31:656-8.

7. Beroukhim RS, Prakash A, Buechel ER, Cava JR, Dorfman AL, Festa P, et al. Characterization of cardiac tumors in children by cardiovascular magnetic resonance imaging: a multicenter experience. J Am Coll Cardiol. 2011;58: 1044-54.

8. Hall JI. Intramural fibroma of the left ventricle. Thorax. 1971;26:481-5.

9. Iwa T, Kamata E, Misaki T, Ishida K, Okada R. Successful surgical ablation of reentrant ventricular tachycardia caused by myocardial fibroma. J Thorac Cardiovasc Surg. 1984;87:469-73.

10. Zerkowski HR, Hentrich F, Doetsch NW, Rohm N. Partial replacement of the left ventricular wall for a large intramural fibroma. Pediatr Cardiol. 1985;6:43-5.

11. Kimura M, Fujino T, Kawachi Y, Kitazato K. Successful excision of right ventricular fibroma associated with ventricular tachycardia: report of six year survival. Jpn Heart J. 1988;29:753-9.

12. Zidere V, Lubaua I, Lacis A. Giant fibroma of the right ventricle. Cardiol Young. 2002;12:584-6.

13. Padalino MA, Basso C, Milanesi O, Vida V, Svaluto G, Thiene G, et al. Surgically treated primary cardiac tumors in early infancy and childhood. J Thorac Cardiovasc Surg. 2005;129:1358-63.

14. Usta E, Hofbeck M, Kaulitz R, Sieverding L, Greil G, Ziemer G. Giant infantile fibroma of the right ventricle-surgical debulking and tumor plication. Thorac Cardiovasc Surg. 2009:57:304-5.

15. António MT, Powell AJ, del Nido PJ. Successful surgical excision of a large left ventricular fibroma in a child. Cardiol Young. 2011;21:595-7.

16. Freire G, Jureidini S, Schowengerdt KO, Rahimi B, Tinker K, Fiore AC. Hybrid procedure for obstructive neonatal left ventricular tumors. Ann Thorac Surg. 2010;90:2057-9.

17. Waller BR, Bradley SM, Crumbley AJ III, Wiles HB, McQuinn TC, Bennett AT. Cardiac fibroma in an infant: single ventricle palliation as a bridge to heart transplantation. Ann Thorac Surg. 2003;75:1306-8.

18. Beghetti M, Haney I, Williams WG, Mawson J, Freedom RM, Gow RM. Massive right ventricular fibroma treated with partial resection and a cavopulmonary shunt. Ann Thorac Surg. 1996;62:882-4.

19. Lee C, Kim SJ, Kim YM. Cardiac fibroma in an infant: complete resection after a Blalock-Taussig shunt as initial palliation. Ann Thorac Surg. 2010;90:1011-4.

20. Grinda JM, Chachques JC, Jouan J, Latremouille C, Deloche A, Carpentier AF. Left ventricular reconstruction after resection of a large fibroma. Ann Thorac Surg. 2001;71:1354-6.

21. Sharma K, Rohlicek C, Cecere R, Tchervenkov CI. Malignant arrhythmias secondary to a cardiac fibroma requiring transplantation in a teenager. $J$ Heart Lung Transplant. 2007;26:639-41.

22. Kobayashi D, L'Ecuyer TJ, Aggarwal S. Orthotopic heart transplant: a therapeutic option for unresectable cardiac fibroma in infants. Congenit Heart Dis. 2011;7:E31-6.

23. Burke AP, Rosado-de-Christenson M, Templeton PA, Virmani R. Cardiac fibroma: clinicopathologic correlates and surgical treatment. J Thorac Cardiovasc Surg. 1994;108:862-70.

24. Cho JM, Danielson GK, Puga FJ, Dearani JA, McGregor CGA, Tazelaar HD, et al. Surgical resection of ventricular cardiac fibromas: early and late results. Ann Thorac Surg. 2003;76:1929-34.

25. Miyake CY, Del Nido PJ, Alexander ME, Cecchin F, Berul CI, Triedman JK, et al. Cardiac tumors and associated arrhythmias in pediatric patients, with observations on surgical therapy for ventricular tachycardia. J Am Coll Cardiol. 2011:58:1903-9. 